\title{
Ocorrência da podridão negra da cenoura no estado do Maranhão
}

\author{
Gilson Soares da Silva, Daline Lorena Moura de Miranda Costa
}

Departamento de Fitotecnia e Fitossanidade, Universidade Estadual do Maranhão, UEMA, CEP 65041-970, São Luís, MA. Autor para correspondência: Gilson Soares da Silva (gilson_soares@uol.com.br)

Data de chegada: 15/11/2012. Aceito para publicação em: 01/10/2013.

A podridão negra das raízes da cenoura (Daucus carotae L.), causada por Thielaviopsis basicola (Sin.: Chalara elegans) é uma doença considerada de pós-colheita, porém pode ocasionar severas perdas de produção no campo. Além da cenoura, esse patógeno é responsável por doenças em mais de 137 espécies de plantas, destacando-se alface, quiabo, algodão, fumo, citros, amendoim, soja e plantas ornamentais. Em março de 2012, foram recebidas para análise, no Laboratório de Fitopatologia da Universidade Estadual do Maranhão, em São Luís, cenouras apresentando lesões de coloração negra que evoluíam para cancros em toda a superfície das raízes (Figura 1). Observações microscópicas do material revelaram a presença de clamidósporos (aleuriósporos) multicelulares, parede grossa, coloração escura, medindo 8,4 x 11,8 $\mu$ m (Figura2A) e grande número de fialósporos (endoconídios) unicelulares, retangulares, produzidos em fiálides, medindo 3,3 $\mu \mathrm{m} \times 19,8 \mu \mathrm{m}$ (Figura 2B). Com base nessas características, o fungo foi identificado como Thielaviopsis basicola. O fungo foi cultivado em meio de BDA mais clorafenicol, em estufa BOD a $25^{\circ} \mathrm{C}$ por dez dias, obtendo-se culturas puras do patógeno. Cenouras sadias, desinfestadas com hipoclorito de sódio a $2 \%$, foram inoculadas depositando-se sobre elas discos de cultura contendo as estruturas do patógeno e incubadas em câmara úmida durante $48 \mathrm{~h}$. Os sintomas foram reproduzidos e o patógeno reisolado, comprovandose os Postulados de Koch. A podridão negra das raízes da cenoura foi descrita há vários anos em diversos países. No Brasil, a podridão negra das raízes da cenoura foi primeiramente relatada no Rio Grande do Sul em 2004 e mais recentemente no Distrito Federal. Esta é a primeira constatação de T. basicola em cenoura no estado do Maranhão.

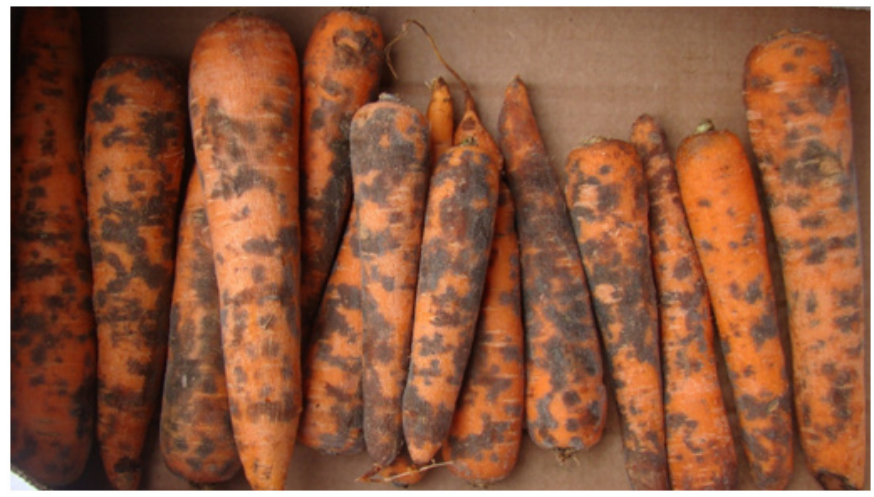

Figura 1. Cenouras com sintomas da podridão negra, causada por Thielaviopsis basicola.

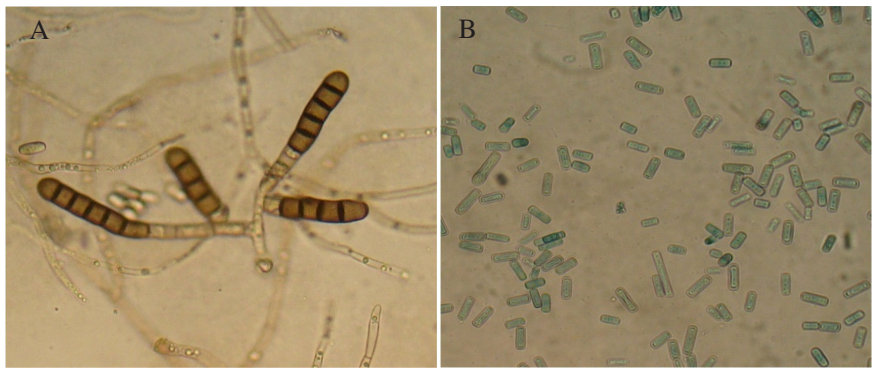

Figura 2. Estruturas de Thielaviopsis basicola.A-clamidósporos; Bendoconídios. 